Peter Bloomfield (published 1003 by by Education 3-13, 31 (3)pp59-67)

Abstract

This paper puts local, national and global citizenship into context post 11.9.01 and pre Johannesburg Earth Summit 2002. It contextulises the strands of the Crick report (1998) and how these integrate with the national curriculum. It argues for a school ethos of citizenship which permeates the whole curriculum rather than a taught citizenship curriculum. The whole notion of citizenship is related to Agenda 21 and Local Agenda 21 and strong bonds are made with Education for Sustainability and Environmental Education.

\title{
What is Citizenship?
}

Schools and teachers often have varying views of what is meant by citizenship. 'It's sharing and caring', 'It's about voting'. Children have views too; 'It's not dropping litter or messing up the area', 'It's playing together and being fair'. All these definitions are, of course, quite acceptable, but are they far reaching enough?

As an environmentalist and geographer I have long held the opinion that if everyone accepted and acted according to Agenda 21 'Blueprint for action in the Twentyfirst Century' ( Quarrie 1992) then we would all be good local, national and global citizens. The pity is that very few have heard of Agenda 21 or its local equivalent, Local Agenda 21.(LA21)

Agenda 21 was conceived at the United Nations Earth Summit in Rio de Janerio in 1992, accepted and signed as a way forward by 180 world leaders. It has four strands:

- To decrease the use of raw materials and energy

- To reduce pollution and waste

- To protect fragile environments

- To share wealth and responsibilities more fairly in consideration of everyone's needs.

These strands may be seen as 'environmental' or 'sustainability' statements and could have economic ramifications. However, if they were part of the daily working documentation of local and national government, of business, commerce, industry and education then maybe we would not need citizenship education.

Given the four strands above I would argue that Agenda 21 includes citizenship education, environmental education and education for sustainability, and more. Seven National Curriculum subjects direct learning for citizenship and sustainability in their 
rationales, so it's not just something we do in Geography! How can we define the differences between these components of LA21, the agenda which effects our schools. Figure 1 attempts to define the terms and put them into context through responses given to questions to teachers about Environmental Education, Education for Sustainability and Citizenship in the primary curriculum.

Figure 1 makes the connections between the three cross curricular ideologies and shows how they sit beneath the LA21 umbrella. These connections are also made in an excellent publication "Rescue Mission Planet Earth" (Peace Child International 1994), a children's Agenda 21, written for young people by young people without the inhibitions of adults getting in the way. In its introduction Boutros Boutros-Ghali, Secretary-General of the United Nations makes the point that it is "no coincidence that Agenda 21 contains a special chapter devoted to children and youth"

2

\section{Environment}

Education about the environment, for the environment in the environment eg litter: why is it bad, what can we do about it?

Let's have a litter pick and stop dropping litter

Education for Sustainable Development

Meeting the needs of today's generation without compromising the ability of future generations to meet their needs.

eg. litter: Where does it come from?

Reduce packaging. reduce landfill, Repair, Reuse, Recycle

\section{Citizenship}

Social and moral responsibility, community involvement and political literacy eg litter: Not messing up the local or global environment for others;

cleaning up, being involved, using the democratic system to solve the problem. (not ignoring it)

Figure 1 Definitions and examples of Environmental Education, Education for

Sustainability and Citizenship in the Primary curriculum.

This paper is being written post September $11^{\text {th }} 2001$, a date which many commentators say marked a change in the focus of citizenship, local, national and most noticeably, global. It is also written before the 2002 Johannesburg Earth Summit, Rio +10 , and questions how these events will, if at all, influence a new Agenda for the twenty first century. The citizenship guidelines and curriculum that have to be delivered in schools are based on the report of the Governmental Advisory Group on Citizenship (Crick 1998) which informed the Citizenship NC to be taught in secondary schools from September 2002.

\section{Implications of the Citizenship Report for schools.}

There are three main strands to what has become known as the 'Crick Report' (1998) and their interpretation is fundamental to the delivery of citizenship in schools. See Figure 2.

1 Social and Moral responsibility Children learning from the very beginning self-confidence and socially and morally responsible behaviour both in and beyond the classroom, both toward those in authority and towards each other.

2 Community Involvement. Learning about becoming helpfully involved in the life and concerns of their neighbourhood and communities, including learning through community involvement and service to the community.

3 Political Literacy. Pupils learning about the institutions, problems and practices of our democracy and how to make themselves effective in the life of the nation, locally, regionally 
and nationally through skills and values as well as knowledge - this can be termed political

literacy, seeking for a wider term than political knowledge alone.

Figure 2. The three strands of citizenship as identified by the 'Crick report' 1998.

\section{Social and Moral responsibility}

The first strand is well known to all primary teachers, from foundation through to KS2. It is the basis we use to teach children to respect each other and those in authority. It is often summarised as 'sharing and caring', forms a rationale for circle time and many assemblies. It helps us define for the children, right from wrong, their responsibilities and their rights. This strand underpins our values and attitudes and while we would hope that all children bring these with them to school it is often found that this is not the case. In some cases teachers work hard to establish very basic values as there is little

3

evidence that the children have any concept of acceptable behaviour. It could be argued that unless this strand of citizenship is taken as the norm in all of the earliest of years of education, then civil society, as we know it, should not be expected as the norm of the future.

\section{Community Involvement}

'Active citizenship' as the second strand has become known, also has its problems for primary teachers and yet is potentially one of the most important for schools. The problems stem from the best of intentions, namely, the safety of the children while at and en-route to and from school.

Through peer pressure parents are made to feel that they are not being a 'good parent' if they do not drive their children to school. All the evidence that the children would be healthier if they walked, the parents healthier and financially better off and the community cleaner and less congested with noisy traffic will not convince the majority of parents. Active citizenship would suggest that children who walk to school, apart from being healthier, will get to know their community and the people in it. The fear of abduction by strangers is given as another reason for driving to school. This, and other issues of neighbourhood safety, is discussed in detail by Mayer Hilman (1998) who cites evidence showing that "children are far more likely to be murdered by a person known to them, and far more are killed by strangers in motor vehicles than by strangers on foot!" (p28)

Active citizenship is about schools being a central part of a local community. Geographical studies from Foundation to Key Stage 2 all concentrate on the 'Local Area'. Sadly, in many cases, teachers need to introduce the children to their own communities, and local studies is an excellent active way to begin this. Given the opportunity through fieldwork activities which may concentrate on environmental trails (nature walks?), following map routes or land use, children begin to understand how their own community works and functions. They may even be able to teach their teacher about the special places where they play or where their friends and relatives live. But still the doors of school are locked (post Dunblane) and notices advise children to Run Yell Tell. Building confidence and community relationships will not happen overnight and will need perseverance to be successful.

Community Involvement may seem a daunting, uphill struggle. It does require all the partners to work together, the children, teachers, head teachers, parents and all the local residents. It needs good working partnerships between the staff room and the 
PTA, the curriculum and local industry and residents associations. When this happens the benefits far outweigh the effort needed to achieve the results. Children feel safer, parents more assured, elderly residents valued. Vandalism may decline, congestion may free-up and school achievement may also increase because teachers will be doing more of what they are good at, teaching, rather than spending time policing and sorting out disputes. Wilkins brings the thinking back to reality given that, "The notion of the 'active citizen' might seem self-evident, since citizenship clearly depends on active participation. However, it is a problematic concept, since the individual is essentially reactive" (Wilkins 2000) and this begs the question, who will take the first action? "Anybody, Somebody and Everybody knew there was a job to be done. Anybody could do it and Everybody thought that Somebody would do it. But in the end Nobody did it" (Peacechild p86)

\section{Political literacy}

Political literacy may seem appear unnecessary in the primary sector and yet where there is evidence of good practice, there is also evidence of children being switched on to the education system. This may seem a threat to some teachers and maybe this is why political literacy is not always visible.

Pupils are in school five days a week, six hours a day. They learn about the school as an institution, its problems and practices and how the 'system' works for them as consumers. Good head teachers recognise this and harness the consumer energy by setting up a school council to allow children to participate in democratic school management, inform future planning and to pre-empt potential problems.

In one school known to the author the council meets every fortnight. It has two representatives from each class from reception to year 6 . Year 6 also facilitate a minutes secretary, agenda secretary, treasurer and chair person as well as representatives to help with feed-back to the early years classes. Children raise issues for the agenda and these typically include provision of milk, state of the toilets, bullying and fair trading of card games (pokemon). This council had even written to the Prime Minister asking for milk in bottles rather than cartons so that they could drink the quantity they wanted without waste, recycle the bottle and wash and re-use a glass rather than create litter with a straw... and they had a reply from P.M. Tony Blair. After meetings the class reps report back to their constituency (with some year 6 children helping in years $R-2$ ) make notes of comments and action suggested and take items for the next agenda.

The extra number of year 6 children on the council help to ensure that all children will have had some time on the council during their time at the school. When the head teacher asked some year 6 reps to brainstorm where they thought the school council fitted into the school as a whole they put it below the head teacher and governors, on a par with the senior management, but above the teachers, PTA, dinner ladies and caretaker. The head teacher agreed that as an integral part of the democracy of the school it did feed into the heirarchy at about that level!

Is this token political literacy, or does it really begin to help inform the children about our democratic system? Certainly the children in the example above know that if they want to be involved they can, but that they have to listen to other points of view and accept the consensus opinion. They know that if they do not vote, the person they do not want to win may do just that and that they may have to accept her/his viewpoint whether they like it or not! Is this not what happened in the 1997 General Election? Is this not the 'right' which thousands of black South Africans queued days for in 1994? 
The children also reinforce (or learn) many skills in organising meetings, note taking, discussion, speaking and listening, fairness, representation and feed-back. This without the pressure of SATs, homework, booster classes, or coercion from teachers or parents builds confidence and life skills.

Within the national curriculum there are many opportunities for inclusion of political literacy. Nelson Mandela can be the focus of study in modern history; planning decisions in the local area bring reality to geography and books such as Oi, get off my train (John Burningham) and Dear Greenpeace (Simon James) can be used at text level in literacy and PHSE.

The three strands could begin to bring together the theoretical and practical concepts and skills which lead to an understanding of democracy, governance, citizenship and interdependence.

It all sounds very heavy for young children, but starting with schools councils, group decisions and local council meetings the strands could lay the foundations for empowerment as future citizens.

The Crick report has informed the Framework for PHSE and Citizenship at KS 1 \& 2 which requires knowledge, skills and understanding to be taught in four interrelated sections:

- Developing confidence and responsibility and making the most of their abilities

- Preparing to play an active role as citizens

- Developing a healthy, safer lifestyle

- Developing good relationships and respecting the differences between people.

Wilkins sees the "most exciting consequence of the work of the Crick Committee may be that it brings 'the vision thing' into the open. Schools can no longer afford to focus narrowly on the national Curriculum, and in addressing education for citizenship, they must first articulate their own vision of citizenship" (Wilkins p27) In working toward this schools will need to address the "processes in values education... rationality, empathy, empowerment and self-esteem and furthering cooperation" (Bottery p10)

\footnotetext{
How do the Strands, the Framework and Agenda 21 relate to the Local, National and Global dimensions of Citizenship?

Before discussing the spatial dimensions of citizenship maybe the question 'Can we teach citizenship?' should be posed. Certainly there are public examination courses commencing in September 2002 at post GCSE level which supposes that we can teach it. Are we failed citizens if we fail the examinations? Can we be convicted but pass the examination in prison and do we then qualify for release? I will return to the concept later. Shah (p159) reminds that "Citizenship can be a very narrow, parochial term but it can also be broad from the point of its meaning and geographical coverage" although "If approached in a critical way they( inequalities) would become relevant to people in any local geographical area, but embedded in personal and collective challenges for a more just world". Citizenship is not without problems between the rich and poor countries where the rich play the NIMBY card (Not In My Back Yard) to buy pollution quotas, exploit cheap labour and buy their way out of responsibility (Bloomfield p135) Local Citizenship
} 
As discussed above, schools are at the heart of communities and as such are immersed in local citizenship. Examples of walking to school, studying the local area, engaging in local decision making were given and are common good practice in many schools. However, the idea of actually engaging with the local community is more difficult. I offer three case studies which are part of ongoing current research here at the University of Hertfordshire. Three St Albans schools seek to develop local citizenship, education for sustainability and curriculum advantages through gardening. These are illustrated in Figure 3 below

Each of the three case studies illustrate a different preference for linking with the local community, each partnership developing the active citizenship as well as an understanding of the other strands. The research, which is funded partly be Hertfordshire County Council, aims to investigate whether these community links and the projects can be included into the curriculum and the community and be seen as sustainable after the university research project and funding cease.

6

All are very much, local, in that they target partnerships which could foster better school-community relations involving senior citizens, ethnic minority mothers and allotment holders. Also at the heart of the projects are practical activities which engage the children in physical activity, promoting a healthier lifestyle and achievable aims with tangible rewards. One head teacher commented, 'All they want to do is dig holes and plant something' but they also like 'sitting on the allotment eating the fresh peas which they have grown'.

The University of Hertfordshire students are in their fourth year of BEd degree and have opted for the Education for Sustainability course as a second specialism. They represent several main specialisms, English, maths, science, geography and art and it is into these subjects that they will be integrating the curriculum links with the school medium term plans. These will be agreed with the school subject co-ordinators and span Foundation to Year 6. If adopted, they begin to support the long term aims of the projects. Figure 4 illustrates, in generic terms, how all subjects can be integrated into gardening activities and vice versa.

Aboyne Lodge JMI and Nursery School.

- Plans for a mini-allotment on school grounds

- Setting up an Allotment Club with parents and Senior Citizens

- Children learning from local Senior Citizens

- University students adapting Medium Term Curriculum Plans to include allotment activities, Citizenship and Education for Sustainability

- Children tend plots, keep diaries and make evaluations of gardening work

- Harvest shared within school and wider community

Camp JMI and Nursery School

- Plans for whole grounds improvement and outdoor growing project

- Target to promote community involvement with parents

- Staff and parents to visit Spitafields City Farm and Community Gardens

- University students adapting Medium Term Curriculum Plans to include allotment activities, Citizenship and Education for Sustainability

- St Albans District Council to prepare allotment site in school grounds

- Children and Mums to develop planting plans, tend and harvest

- Staff monitoring motivation, involvement and achievement

- Celebrating by sharing harvest. Community comes to school

Spencer Junior

- Allotment club already established on neighbouring council site

- St Albans District Council to prepare allotment site 
- Change format to include all children in the project

- Re-run the successful Gardeners Question Time with School Council and local allotmenters (previously run with visiting Chinese educators)

- University students adapting Medium Term Curriculum Plans to include allotment activities, Citizenship and Education for Sustainability

- Children keep diaries, make photographic diary, continue gardening

- Develop herb garden and bog garden to attract helpful wildlife

- Continue to make compost and leaf mould, develop compost wormery

- Develop stronger links with Allotment Association and community

- Staff monitor self esteem, motivation, and curriculum innovation

- Share harvest within school and community, keep seeds for next year

Figure 3 Case studies demonstrating school gardening-community citizenship links 


\begin{tabular}{|c|c|c|}
\hline - English & $\begin{array}{l}\text { Reading, catalogues/ literature } \\
\text { speaking and listening, } \\
\text { formal \& creative writing } \\
\text { comprehension } \\
\text { use of language }\end{array}$ & $\begin{array}{l}\text { To council to secure plot, to tell } \\
\text { parents and school; to discuss plants, } \\
\text { organic or not; understanding of } \\
\text { appropriate literature \& language } \\
\text { e.g. the poetry of plants }\end{array}$ \\
\hline - Maths & $\begin{array}{l}\text { Shape, space, measuring, } \\
\text { number } \\
\text { handling data }\end{array}$ & $\begin{array}{l}\text { Planning plot, dividing areas } \\
\text { numbers of seeds, plants } \\
\text { measuring plot, weighing produce } \\
\text { recording data, graphs etc }\end{array}$ \\
\hline - Science & $\begin{array}{l}\text { Scientific enquiry } \\
\text { Life processes \& } \\
\text { living things } \\
\text { Classification. } \\
\text { Materials \& properties } \\
\text { Physical processes }\end{array}$ & $\begin{array}{l}\text { Planning, evidence, evaluation } \\
\text { Green plants; growth, nutrition } \\
\text { reproduction. Variation and } \\
\text { Living things and } \\
\text { their environment. } \\
\text { Grouping, classifying, changing } \\
\text { effect of light; seasonal variation }\end{array}$ \\
\hline - Design \& Technology & $\begin{array}{l}\text { Skills, knowledge \& } \\
\text { understanding }\end{array}$ & $\begin{array}{l}\text { Developing, planning ideas } \\
\text { Working with tools, equipment, } \\
\text { materials; evaluating processes } \\
\text { Health and safety. }\end{array}$ \\
\hline - History & $\begin{array}{l}\text { Chronological understanding } \\
\text { Historical Enquiry } \\
\text { Historical interpretation }\end{array}$ & $\begin{array}{l}\text { A local study, allotment evolution } \\
\text { Britain since } 1930 \\
\text { e.g. 'Dig for victory' }\end{array}$ \\
\hline - Geography & $\begin{array}{l}\text { Skills, knowledge and } \\
\text { understanding } \\
\text { Knowledge \& understanding } \\
\text { of places } \\
\text { Local Study } \\
\text { Contrasting locality }\end{array}$ & $\begin{array}{l}\text { Geographical enquiry, observation, } \\
\text { evidence, mapping, recording } \\
\text { Where is it ? weather, patterns and } \\
\text { processes, environmental change } \\
\text { and issues, sustainable development } \\
\text { contrasting foods, wider world } \\
\text { sources; interdependability }\end{array}$ \\
\hline - Art and Design & $\begin{array}{l}\text { Skills, knowledge and } \\
\text { understanding }\end{array}$ & $\begin{array}{l}\text { exploring colour, pattern, texture, } \\
\text { line, tone, shape, form, space in } \\
\text { natural and made objects and } \\
\text { environments }\end{array}$ \\
\hline - Music & Breadth of study & $\begin{array}{l}\text { use different stimuli, musical and } \\
\text { non musical }\end{array}$ \\
\hline - Physical Education & Breadth of study & $\begin{array}{l}\text { Exercise safely; orientation, problem } \\
\text { solving, collaboration in groups }\end{array}$ \\
\hline$\cdot I C T$ & $\begin{array}{l}\text { Finding things out } \\
\text { Developing ideas } \\
\text { Exchanging/ sharing data }\end{array}$ & $\begin{array}{l}\text { Searching Internet, or a CD-ROM } \\
\text { desktop publishing, spreadsheets etc. } \\
\text { e-mail, displays, posters, writing to council, } \\
\text { parents, local community and other pupils }\end{array}$ \\
\hline RE & $\begin{array}{l}\text { Learning about religion } \\
\text { Learning from religion }\end{array}$ & $\begin{array}{l}\text { Harvest festivals, stories about creation } \\
\text { natural world } \\
\text { Awe and wonder, thankfulness, responsibility }\end{array}$ \\
\hline
\end{tabular}

Figure 4. Application of gardening across the national curriculum \& RE 


\section{National Citizenship}

"In all countries of the world, rich and poor, they (children) are the first to suffer from poverty, malnutrition, disease and pollution." Boutros Boutros- Ghali (1994). To take citizenship from a local level to a regional and national dimension may need more thought. County councils and regional bodies do have strategies to involve children and are often very willing to be involved. In France 700 towns and villages have a children's shadow council which monitors the adult council work and approves their decisions. "The movement has had an impact right up to national level: politicians see it as a way of giving young people experience in democracy and getting them interested in their local communities. The idea has spread to Italy, Austria and Germany" (Peacechild p87) National citizenship always seems outside the experience of the child and yet children readily identify with other national experiences such as national teams in sporting events, national boundaries, national flags and national heads of state or royalty. Maybe it needs to be made more obvious that adults vote for a national government who make national laws which we abide by. We all understand national conventions such as driving on the left and stopping at cross roads.

Everyday there are national issues in the media which children hear about, or see on the television, which affect them. Issues which involve the Rights of the Child, fair trade, racism, homeless children begging and countless others. Incidents which grab the headlines such as the race riots on Bradford and English football hooliganism are issues on which children should be challenged. Is it right? Should it be allowed? How can it be stopped? Has it happened near you? and What would you do? are all questions which could be addressed using national newspapers as stimulus for discussion across several subjects in the curriculum. Unless children are helped to identify with the national picture they will grow into disaffected young people without national roots.

\section{Global Citizenship}

Ask children to identify where their food comes from, where their clothes are made and the location of the TV programmes they watch and there is the basis for a session on global citizenship and interdependence.

We all come complete with global baggage and media brainwashing. I show children and adults four pictures and ask them to say where in the world they think they are. Figure 5 has descriptions of the slides and a selection of typical adult responses.

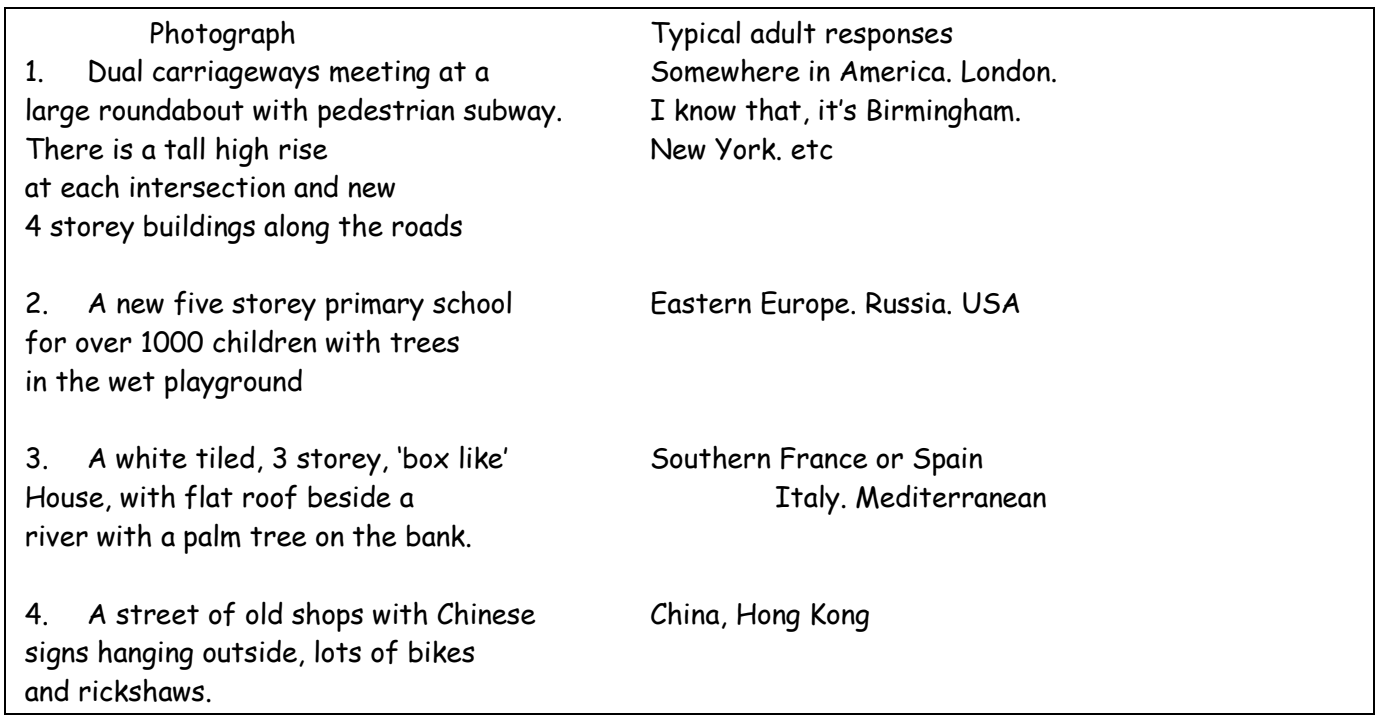


Figure 5. Photographs taken in Foshan, Near Canton China, and typical adult responses.

9

The photographs are shown as slides in quick succession and repeated in reverse.

Responses are often highly defended 'I had a friend who lived there' etc. Only when I reveal that all the photographs are taken within a mile of the last one, in Foshan, China, is there any cause for concern. We discuss media conditioning and how we view the world from a rich, western perspective and do not really think that other places around the globe could be like our world! We discuss how children are growing up with the same messages and that we need to be aware of this before we begin to talk about global issues in the classroom. Try this yourself; substitute China Town, London for the last photograph; include poverty from the UK and wealth from a developing country! Excellent materials are available for teaching about global citizenship, The Non Government Organisations (NGOs) produce resources at all levels for use in many subjects. A summary of knowledge and understanding, skills and values and attitudes are well set out in the Oxfam Curriculum for Global Citizenship. (1997). The Central Bureau (Aitken 2000) offer a primary case studies video and MUNGA (Model United Nations General Assembly) in action. Children take on the roles of specific countries and stay in role all day debating controversial issues with other schools under the leadership of an Assembly Controller. The accompanying booklet contains activities for inset and classroom. Global citizenship is also well taught through 'world studies' and the World Studies Trust (Steiner 1993) support this work at all levels.

If teachers are to help children understand global citizenship in a post September $11^{\text {th }}$ 2001 world then there may need to be some teacher reflection concerning the choices of materials and curriculum to be taught. What we leave out is as important as what we include. In the words of Steiner, "Holding a value or an attitude about something does not lead to any specific action or, necessarily, to any action at all. Inaction is itself a moral choice" (Steiner p12) She goes on to present a letter written from an American High School principal to his staff on the first day of school. Figure 6

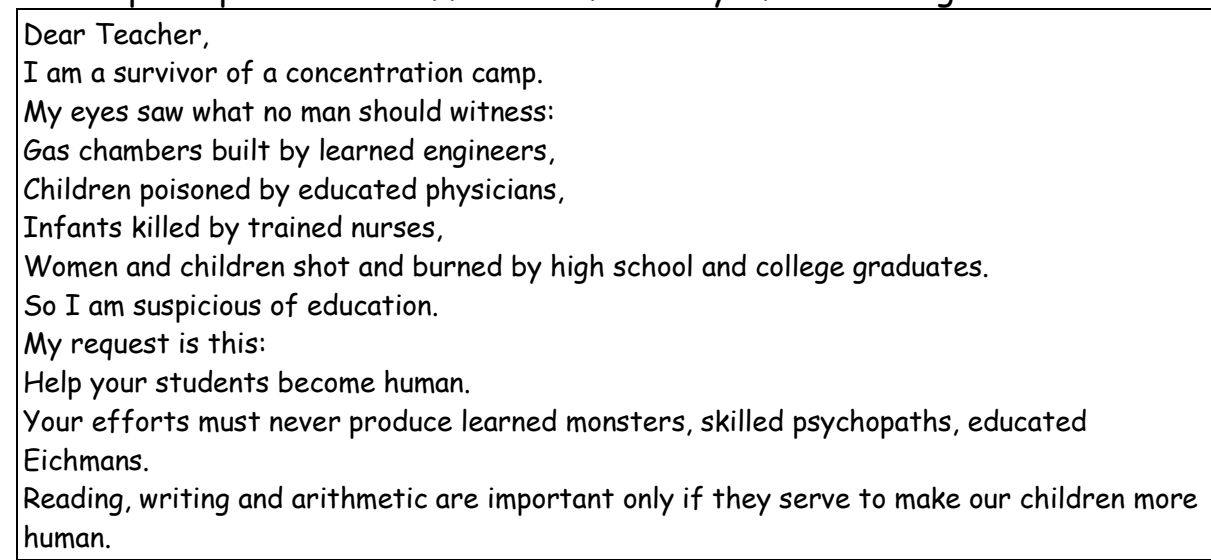

Figure 6. Letter from principal of an American High School to his staff on the first day of school. (source: Steiner p12)

Cameo case studies and examples of materials do not automatically ensure that citizenship local, national or global are taught. Like other subjects it has to be planned into the curriculum, it needs a school policy so that the whole staff pull in the same direction. How should it be taught? Is it a new subject or should it be integrated into the existing schemes of work and school planning? All will take careful thought and integrated planning if the children are not to be confused or, worse, turned off. 
Colleagues need to reflect on their own credentials, values and attitudes, to understand the complexities of citizenship before ticking off the boxes!

\section{Future Citizens}

We educate children for their future, the important word is 'their'. We educate them for employment, relationships, recreation and leisure. Do we consider what sort of world we are educating them for or how they will survive in that world? We are educating the administrators of our pensions, our retirement managers; how will they view us as senior citizens if we have not taught them the values and attitudes we uphold as those of good citizens? If they see 'making a fast buck' as more important than caring and sharing, if they would rather not give up an hour to help someone or they don't understand the importance of getting involved in decision making then, even with all the qualifications in the word, we may have failed them. However we must be careful not to burden them with all the doom and gloom of the world; " to study only the problems of society can be an alienating experience for pupils: they also need opportunities to explore what sort of future they want for themselves and society, and the action needed to help bring that future about" (Hicks 2001). Hicks discusses the personal, social, temporal and spatial nature of futures citizenship. He suggests that children articulate the sort of world they would like to live in by drawing spider diagrams of what they see as a good future and offers examples such as 'a world without war', 'a world without drugs', and 'a world where there are no kidnappers'. (Hicks p5) It would seem that some children already have a pretty unpleasant view of society.

But can we teach citizenship for the future? Many years ago I taught environmental studies and citizenship in sixthform general studies. We tried to address all three strands of the Crick report long before it was written. As active citizenship the group cleared a village pond of the accumulated debris. One student featured in a large photograph across the local paper pulling an old gate out of the pond; hero of the hour. The day after publication the same student was walking to school, beside the pond, and was seen by the Deputy Head to throw a drinks can over a fence, into a garden. Back at school the student was questioned about his actions but could not make any link between the two events. One was taught, the other in his own time and therefore, in his mind, nothing to do with school. This is an isolated example but serves to illustrate the complexity of teaching citizenship as a life skill. If citizenship is part of the formal curriculum it might be seen as 'just a taught subject', if it is at the heart of the thinking of the school, if it is cross curricular, part of everyday school life, with occasional subject specific sessions, it may have a chance. Passing an examination in citizenship will not guarantee good citizens. Pupils as part of a school council may do more to inform future citizens about political literacy and how to effect change in society. Pupils today talk to each other more than ever before. That they use computers and mobile phones to communicate extends the range of communication. Young people can span the local, national and global dimensions of citizenship in seconds. If teachers can provide the opportunities to harness this lust for electronic communication, to stimulate national and global citizenship enquiry, they will at least have engaged children in a process of developing worthwhile life skills. And we cannot start too early, "We are all citizens and citizenship education begins at an earl age..... active citizenship needs to be encouraged, celebrated and rewarded" (Turner p2). 
Agenda 21 encompasses all the strands of citizenship, it embraces education for sustainability and environmental education, in short, it sets out the agenda for an optimistic future for all citizens. Are we integrating all the strands and dimensions in teaching children the values and attitudes necessary for survival as citizens of the future?

As educators the choice is ours but we must question whether we are getting it right?

- Can we 'teach' citizenship?

- Could we create ' citizenship fatigue'?

- Are we making the right connections?

- Is there too much 'recycling' and not enough depth of content?

- How can we help children vision their futures? and

- How do monitor our success?

Peter Bloomfield

Senior Lecturer in Geographical Education

Department of Education

University of Hertfordshire

March 2002 


\section{References}

Aitken L,. 2000, Developing Global Citizens in Primary Schools, The Central Bureau for International Education and Training, London

Bloomfield P., 2000, in Shah S.,(Ed) Equality Issues for the New Millennium. Chapter 12 , Responding locally to Global Inequality, Ashgate, Aldershot.

Bottery M., 2000, in Bailey R., (Ed) Teaching Values \& Citizenship across the curriculum: Chapter 1, Values Education. Kogan Page, London

Boutros-Ghali B., 1994 in Rescue Mission Planet Earth, Peachchild International, Kingfisher, London.

Crick B., 1998, Education for citizenship and the teaching of democracy in schools,

Qualifications and Curriculum Authority, London

Hicks, D. 2001, Citizenship for the future, WWf-UK. Godalming

Hilman. M., 1998 in Scoffhan S. (Ed) Primary Sources. Research

findings in primary geography. Geographical Association, Sheffield Oxfam 1997, A curriculum for Global Citizenship, Oxfam , London Peacechild International, 1994, Rescue Mission Planet Earth, Kingfisher, London

Quarrie J., (Ed) 1992, Earth summit 1992: The United Nations Conference Report on Environment and Development, Rio de Janerio. Regency Press, London.

Shah S., ( Ed) 2000, Equality Issues for the New Millennium. Ashgate, Aldershot. Steiner, M. 1993, Learning from Experience: World studies in the primary curriculum. Trentham Books, Stoke-on-Trent

Turner, S., 1999, Luton Infant Citizenship Project, Institute for Citizenship, London.

Wilkins C., 2000, in Bailey R., (Ed) Teaching Values \& Citizenship across the curriculum: Chapter 2, Citizenship Education. Kogan Page, London 